\title{
The vegetation of recently fallowed Masakwa fields in the Chad basin
}

\author{
Mandingo Ataholo \& Rüdiger Wittig
}

Summary: On the clay plains surrounding Lake Chad (West Africa: northern Sudanian and southern Sahelian zone), certain varieties of pearl millet (Sorghum bicolor), commonly referred to as Masakwa, are cultivated during the dry season. Recently fallowed Masakwa fields support a particular progression of pioneer vegetation. In the first year of fallow, the pioneer vegetation typically belongs to the class Echinochloetea colonae Wittig 2005 and can be classified as Hygrophiletum auriculatae sensu lato. Approximately half of the stands consist of the Hygrophiletum auriculatae Ataholo 2002 sensu stricto, whereas the other half is primarily composed of a Celosia argentea-Hibiscus trionum community. After two years of fallow, the vegetation is typically formed by the Sorghetum arundinacei Ataholo 2002, which, in a few cases, can also occur in the first fallow year.

Keywords: Echinochloetea colonae, firgi, Hygrophiletum auriculatae, Nigeria, Sahelian zone, Sorghetum arundinacei, Sorghum bicolor, Sudanian zone

\section{La végétation des JeUnes Jachères d’anciens Champs de Masakwa dans le Bassin du TChad}

Résumé: Sur les sols argileux de la plaine autour du Lac Tchad (Afrique de l'Ouest: zones Soudanienne au Nord et Sahélienne au Sud), des variétés particulières de petit mil (Sorghum bicolor) toutes regroupées sous le terme Masakwa, sont cultivées pendant la saison sèche. Les jeunes jachères issues d'anciens champs de Masakwa forment un type particulier de végétation pionnière. Cette végétation au cours de la première année et dans la majorité des cas, fait sans doute partie de la classe d'Echinochloetea colonae Wittig 2005, et classée comme Hygrophiletum auriculatae sensu lato. Près de la moitié des peuplements constitue le Hygrophiletum auriculatae Ataholo 2002 sensu lato, tandis que l'autre moitié est formée en majorité par le Celosia argentea-Hibiscus trionum. Dans les champs de deux ans, on retrouve normalement le Sorghetum arundinacei Ataholo 2002, qui dans certains cas apparait déjà au cours de la première année de jachère.

Mots clés: Echinochloetea colonae, firgi, Hygrophiletum auriculatae, Nigeria, Sorghetum arundinacei, Sorghum bicolor, zone Sahelienne, zone Sudanienne

\section{Die Vegetation junger Brachen der Masakwa-Felder in der Tschad-Ebene}

Zusammenfassung: Auf den Tonebenen des Tschadbeckens (West Afrika: südliche Sahel- und nördliche Sudanzone) werden bestimmte Sorten der Perl-Hirse (Sorghum bicolor) unter dem Sammelnamen Masakwa kultiviert. Junge Brachen von Masakwa-Feldern tragen im ersten Jahr in der Regel eine zur Klasse Echinochloetea colonae Wittig 2005 gehörende Pioniervegetation, die im weiteren Sinne dem Hygrophiletum auriculatae Ataholo 2002 zugeordnet werden kann. Etwa die Hälfte der Bestände repräsentiert das Hygrophiletum auriculatae s.str., die ancdere Hälfte wird meist von einer Celosia argenteaHibiscus trionum-Gesellschaft gebildet. Auf zwei Jahre lang brach liegenden Feldern findet man meist das Sorghetum, arundinacei Ataholo 2002, das in seltenen Fällen auch gleich im ersten Brachejahr auftreten kann.

Schlagworte: Echinochloetea colonae, firgi, Hygrophiletum auriculatae, Nigeria, Sahelzone, Sorghetum arundinacei, Sorghum bicolor, Sudanzone

\section{INTRODUCTION}

Within the clay planes surrounding Lake Chad (West Africa: northern Sudanian and southern Sahelian zone), certain varieties of pearl millet (Sorghum bicolor; see DAHLBERG 2001), commonly called Masakwa, are cultivated during the dry season (Olabanji 1999, Neumann 2001). Because cropping in the dry season within the Sudanian and Sahelian zone represents a particularity, the fallow vegetation of these fields is of great interest for vegetation science. Furthermore, in the context of increasing populations (KRINGS 2002), the shrinking of Lake Chad (THIEMEYER 2002) and climate change, it is doubtful whether the very laborious traditional dry season cultivation will be maintained in the fu- ture. Therefore, we present a study of the fallow vegetation of the dry season fields at Lake Chad.

\section{Area of investigation}

All relevés were taken in the year 1995 in the area near Marte and Ngala (Nigeria) according to the method of BRAUNBLANQUET (1964). The area of our investigation was located in the Sudanian zone near the border of the Sahelian zone (White 1983). In this area, as well as in other areas in the vicinity of Lake Chad, a particular traditional method of dry season cultivation is used, which is based on the high water retention capacity of the soils that have developed on the lagoonal plains of Chad (called firgi in the Kanuri language). The soils and landscape in the vicinity of the Nigerian shore of Lake Chad were intensively surveyed by researchers from the Goethe-University of Frankfurt (Germany) within the framework of the Collaborative Research Center 268 (Sonderforschungsbereich 268). Additional detailed informati- 
on on this area can be obtained from publications resulting from this investigations (e.g., FrANKE-SCHARF 1997, 2000, Kirscht 2001, NeUMANN 2001, SkORUPINSKy \& FranKeSCHARF 1997, THIEMAYER 1997a, b) or from the review of FRANKE-SCHARF et al. (2004). The linguistic background of the term Masakwa was addressed by LöHR (2001).

Because of the low infiltration rate of clay soils, dykes of 0.5 to $0.75 \mathrm{~m}$ high have been built around the fields to impound rainwater, prevent run-off and increase infiltration. In August, which is part of the rainy season, sorghum nurseries are prepared while the dry season fields are still flooded. Several weeks later, when the firgi are dry, the spontaneous vegetation ("weed vegetation") of the fields is removed, and four- to six-weeks-old seedlings are planted (for additional details of the planting procedure, see OlabanJI 1999). At this time, the surface of the firgi has become dry and hard and becomes largely impenetrable for the roots of germinating weeds. Therefore, one or two weeding events are sufficient to achieve a minimal weed cover. The complete potential weed community can only be observed on recently fallowed fields.

\section{Results}

We identified two plant communities on the fallowed Masakwa fields: Hygrophiletum auriculatae sensu lato (3.1) and Sorghetum arundinacei (3.2).

\subsection{Hygrophiletum auriculatae sensu lato}

After one year of fallow, Masakwa fields are covered by dense vegetation (covering $65-98 \%$; average $87 \%$ ) that is typically dominated by one or several of the species Celosia argentea, Hibiscus trionum, Cyperus esculentus and/or Hygrophila auriculata, Momordia balsamina and, more rarely, by Ipomoea aquatica. Nearly all of the species that occur with medium to high constancy prefer humid or temporarily wet soils. According to Le BourgeoIs \& MerLIER (1993), a high proportion of these species are classified as indicators of vertisols and/or clay or a high soil pH. ATAHOLO (2002) demonstrated that approximately $75 \%$ of the species found in this community are indicators of heavy soils, and $55 \%$ are indicators of alkaline soils. Obviously, the vegetation of fallowed Masakwa fields closely mirrors the soil conditions (Mordi et al. 1991) of the firgi.

Greater than $50 \%$ of the relévés taken of this vegetation (Table 1, No. $1-7$ ) can be identified as belonging to the Hygrophiletum auriculatae $s$. str., which was described by ATAHOLO (2002). This association is one of the two communities that represent the class Caperonietea palustris Ataholo 2002; however, no valid description of this class presently exists. WiTtig (2005) assigned this community to the alliance Aeschynomenion indicae Wittig 2005 within the class Echinochloetea colonae Wittig 2005. In a broader sense, the remaining five relévés also belong to the Hygrophiletum auriculatae because of their similar species composition and identical habitat. When the guidelines of BRAUN-BLANQUET (1964) are strictly followed, these relévés must be regarded as representing a rankless community for which ATAHOLO (2002) has proposed the name Celosia argentea-Hibiscus trionum community.

\subsection{Sorghetum arundinacei Ataholo 2002 nom. corr.}

After two years, fallowed fields are covered by the Sorghetum arundinacei Ataholo 2002 nom. corr. (Table 2), which is a grass-dominated vegetation that covers $80-95 \%$ (average $88 \%$ ) and often reaches a height of $3 \mathrm{~m}$. In most stands, Sorghum arundinaceum is dominant, in a few cases Momordica balsamina shows the highest cover. Rarely, Merremia emarginata, Echinochloa colona or Sorghum bipinnatum were found to be codominant. Similar to the oneyear fallows, Hibiscus trionum, Celosia argentea and Caperonia palustris show high to very high constancy. According to ATAHOLO (2002), indicators of clay and of alkaline soils are strongly represented, which is similar to the vegetation of the recently fallowed fields described above. In a few cases, the Sorghetum arundinacei was observed in one-year fallows. These stands, which are represented by relévé No. 2 in Table 2, were of a much lower height than those of the older fallowed fields.

Because only a few relévés are available, the position of this association within the phytosociological system is arguable. Therefore, it is desirable to obtain additional relévés of this community as well as of the pioneer vegetation of other temporarily inundated argillaceous soils in the Sudanian and Sahelian zone.

\section{Discussion}

The ecological conditions of recently fallowed and temporarily inundated fields are very similar to that of disturbed areas at the shores of lakes or in depressions with argillaceous soils and of the dry fallen soils of temporary waters (called mares in French). In all cases, wet bare soil exists and remains humid during the first weeks of the dry season. Therefore, germination conditions are excellent and competition is, at first, very low. Therophytes dominate the resulting vegetation, but seedlings of perennial species common in later successional stages, and of the adjacent communities, might be present. The therophytes comprise three groups:

- Ubiquitious species found at the majority of disturbed sites,

- Species that mainly occur in cultivated fields (i.e., agricultural weeds s.str),

- Species with a unique ecological adaptation to these temporarily inundated (or temporarily wet) and periodically disturbed habitats. These species form the core of the class Echinochloetea colonae Wittig 2005.

The Hygrophiletum auriculatae represents a key example of this type of vegetation: the class Echinochloetea colonae is represented by its name-giving species (Echinochloa colo$n a)$ and by a character species of one of its associations ( $H y$ grophila auriculata). Agricultural weeds s.str. are present (e.g., Celosia argentea, Corchorus olitorius and Commelina nigritana), and Sida alba represents the group of ubiquists. Cyperus esculentus, Oryza barthii and Echinochloa stagnina are mainly considered reed species.

As the succession continues, species that are taller than the aforementioned plants become dominant such that the dimensions of the vegetation are completely altered. The 
Table / Tableau 1: Hygrophiletum auriculatae and Celosia argentea-Hibiscus trionum community

\begin{tabular}{|c|c|c|c|c|c|c|c|c|c|c|c|c|}
\hline No. & 1 & 2 & 3 & 4 & 5 & 6 & 7 & 8 & 9 & 10 & 11 & 12 \\
\hline No. in Table 57 of Ataholo 2002 & 4 & 5 & 12 & 3 & 6 & 16 & 7 & 2 & 8 & 10 & 11 & 14 \\
\hline vegetation cover $(\%)$ & 95 & 90 & 90 & 80 & 98 & 95 & 80 & 75 & 90 & 65 & 80 & 95 \\
\hline height of the vegetation (m) & 0.6 & 0.6 & 0.5 & 0.5 & 0.6 & 0.4 & 0.8 & 0.4 & 0.5 & 0.3 & 0.4 & 0.4 \\
\hline relévé area $(\mathrm{m} 2$ x 10) & 40 & 60 & 60 & 40 & 50 & 90 & 12 & 50 & 60 & 40 & 90 & 90 \\
\hline \multicolumn{13}{|l|}{ C Hygrophyletum auriculatae } \\
\hline Hygrophila auriculata & 5 & 2 & 1 & 2 & 3 & 2 & + & . & . & . & . & . \\
\hline \multicolumn{13}{|c|}{ C and D* of the Aeschynomenion indicae } \\
\hline Caperonia palustris & 1 & + & 1 & 1 & 1 & . & . & . & 1 & 1 & 1 & 2 \\
\hline Cyperus esculentus & . & . & 2 & 2 & 2 & 3 & . & 2 & 4 & 2 & + & 3 \\
\hline Ipomoea aquatica & . & 1 & 2 & 3 & . & 1 & 1 & 1 & 1 & . & . & 1 \\
\hline Oryza barthii & 1 & 1 & . & . & 3 & . & . & . & . & . & . & . \\
\hline Aeschynomene indica & . & . & . & 2 & . & . & . & . & . & + & + & . \\
\hline Echinochloa stagnina & . & . & . & . & . & 1 & . & . & . & . & . & . \\
\hline Centrostachys aquatica & . & . & . & . & . & . & 1 & . & . & . & . & . \\
\hline \multicolumn{13}{|l|}{ C of the Echinochloetea colonae } \\
\hline Echinochloa colona & . & . & . & . & 1 & 1 & 3 & . & 3 & . & . & . \\
\hline \multicolumn{13}{|c|}{ Indicators of clay and/or vertisols** } \\
\hline Celosia argentea & 1 & 4 & 3 & 1 & 1 & 2 & + & 2 & 1 & 1 & 2 & 2 \\
\hline Ocimum canum & . & + & . & . & + & . & + & + & + & + & + & . \\
\hline Merremia emarginata & . & . & . & . & . & . & + & 1 & 1 & . & . & 1 \\
\hline Corchorus olitorius & . & . & . & . & . & . & 1 & . & + & . & . & 2 \\
\hline Phyllanthus maderaspatensis & . & . & . & . & . & . & . & 1 & 1 & 1 & . & . \\
\hline Corchorus fascicularis & . & + & . & . & . & . & . & . & + & . & . & . \\
\hline \multicolumn{13}{|l|}{ companions } \\
\hline Hibiscus trionum & 2 & 2 & 4 & . & 1 & 2 & . & 2 & 1 & 3 & 2 & 3 \\
\hline Momordica balsamina & . & . & . & . & . & 4 & 1 & 3 & . & 2 & . & 3 \\
\hline Sida alba & . & . & . & . & + & + & . & + & . & . & + & . \\
\hline Commelina nigritana & . & 3 & . & . & . & . & . & 2 & 2 & . & . & . \\
\hline Aeschynomene americana & 1 & . & . & . & + & . & . & . & . & . & . & . \\
\hline Abutilon pannosum & . & . & . & . & . & 1 & . & . & . & . & . & 2 \\
\hline Aeschynomene sensitiva & . & . & . & . & . & 1 & . & . & . & . & . & 2 \\
\hline Euphorbia forsskalii & . & . & . & . & . & . & + & + & . & . & . & . \\
\hline Calotropis procera & . & . & . & . & . & . & + & . & . & + & . & . \\
\hline Lagera oloptera & . & . & . & 2 & . & . & . & . & . & . & . & . \\
\hline Acroceras amplectens & . & . & . & . & . & . & 3 & . & . & . & . & . \\
\hline Acacia seyal (juv.) & . & . & . & . & . & . & 2 & . & . & . & . & . \\
\hline Hibiscus panduriformis & . & . & . & . & . & . & 1 & . & . & . & . & . \\
\hline Chloris barbata & . & . & . & . & . & . & 1 & . & . & . & . & . \\
\hline Sida alba & . & . & . & . & . & . & 1 & . & . & . & . & . \\
\hline Merremia hederacea & . & . & . & . & . & . & . & . & 3 & . & . & . \\
\hline Phyllanthus amarus & . & . & . & . & . & . & . & . & 1 & . & . & . \\
\hline Chlorophytum pusillum & . & . & . & . & . & . & . & . & 1 & . & . & . \\
\hline Pennisetum violaceum & . & . & . & . & . & . & . & . & . & . & . & 1 \\
\hline
\end{tabular}

Additionally with + in relévé No.1: Leucas martinicensis; in No.2: Cucumis melo var. agrestis; in No.7: Citrullus colocynthis, Sesbania leptocarpa, Indigofera senegalensis, Leptadenia hastata, Cassia tora, Achyranthes sicula, Panicum mueense; in No.9: Eragrostis atrovirens, Ipomoea coptica, Portulaca oleracea, Commelina africana var. africana; in No.12: Ludwigia octovalvis.

* all species of reed communities and other amphibious habitats

** mentioned by Le BouRGeOIS \& MERLIER (1995) 
Table / Tableau 2: Sorghetum arundinacei

\begin{tabular}{|l|c|c|c|c|c|}
\hline relévé no. & 1 & 2 & 3 & 4 & 5 \\
\hline Table no. in Ataholo (2002) & 58 & 58 & 58 & 57 & 57 \\
\hline vegetation cover (\%) & 90 & 80 & 85 & 90 & 95 \\
\hline height of the vegetation (m) & 3 & 3.5 & 3 & 0.4 & 1.5 \\
\hline relévé area (a) & 9 & 9 & 9 & 9 & 5 \\
\hline Character species & & & & & \\
\hline Sorghum arundinaceum & 5 & 4 & 3 & 2 & 3 \\
\hline Other species & & & & & \\
\hline Hibiscus trionum & 1 & 2 & 2 & 1 & 2 \\
\hline Momordica balsamina & 2 & 2 & 2 & 4 & 1 \\
\hline Celosia argentea & + & + & 2 & 2 &. \\
\hline Echinochloa stagnina & + & 1 & 1 & 1 &. \\
\hline Abutilon pannosum & + & 1 & 2 & + &. \\
\hline Phyllanthus maderaspatensis & + & + & + & + &. \\
\hline Cyperus esculentus & 2 & 2 & 2 & 2 &. \\
\hline Caperonia palustris & 1 & 2 & 2 &. & 1 \\
\hline Sida alba & + & 1 & + &. &. \\
\hline Merremia emarginata &. & + & + & 3 &. \\
\hline Gynandropsis gynandra & + & + &. &. &. \\
\hline Euphorbia forsskalii & + & + &. &. &. \\
\hline Hibiscus scotelii & + & + &. &. &. \\
\hline Echinochloa colona &. & + &. &. & 3 \\
\hline Corchorus olitorius &. &. & + &. & 2 \\
\hline Leucas martinicensis &. &. & 1 &. &. \\
\hline Ipomoea aquatica &. &. &. & 1 &. \\
\hline Aeschynomene sensitiva &. &. &. & 1 &. \\
\hline Sorghum bipennatum &. &. &. &. & 3 \\
\hline Hibiscus panduriformis &. &. &. &. & 2 \\
\hline Bidens pilosa &. &. &. &. & 1 \\
\hline & & & & \\
\hline
\end{tabular}

Additionally with + in relévé No.1: Pennisetum violaceum, Rhyncosia minima; in No.3: Cassia obtusifolia, Aeschynomene indica, Bidens pilosa; in No.4: Phyllanthus amarus.

species composition, however, does not substantially vary: eight of the eleven species with a constancy class of III - V in Hygrophiletum auriculatae also occur in Sorghetum arundinacei at a constancy class III or greater; and also eight of the eleven species that occur with intermediate to very high constancy in the Sorghetum arundinacei are present in Hygrophiletum auriculatae at class III or greater.

As shown above, the Hygrophiletum auriculatae clearly belongs to the Echinochloetea colonae. Further investigations are needed to clarify whether the Sorghetum arundinacei also can be assigned to this vegetation class or whether it forms the core of a separate class, i.e., the Caperonietea palustris proposed by ATAHOLO 2002.

\section{References}

Ataholo M (2002): Pflanzensoziologische Untersuchungen der Segetalvegetation in der Sudanzone Westafrikas. Diss., J.W. Goethe-Universität, Frankfurt am Main.

Braun-Blanquet, J (1964): Pflanzensoziologie - Grundzüge der Vegetationskunde. - Springer, 3. Aufl., Wien, 865 p.

DAHLBERG JA (2001): Classification of masakwa sorghum from Lake Chad. Ber. SFB 268 17: 15-22.

FRANKE-SCHARF I (1997): Landnutzungswandel im nigerianischen Tschadbecken. Kartierungen aus Luftbildern von 1957 bis 1990. Ber. SFB 268 9: 35-51.

FRANKE-SCHARF I (2000): Integration of land use and related information within a geographic information system of the Chad Basin in NE-Nigeria. Ber. SFB 268 14: 105-114

Franke-Scharf I, Kirscht H, Krings M, Platte E \& ThieMEYER H (2004): Der Tschadsee: Seespiegelschwankungen und wechselnde Nutzungspotenziale. In ALBERT KD, LÖHR, D. \& Neumann K (eds.): Mensch und Natur in Westafrika. Ergebnisse aus dem Sonderforschungsbereich 268 "Kulturentwicklung und Sprachgeschichte im Naturraum Westafrikanische Savanne". Wiley-VCH Verlag, Weinheim,196-220.

KIRSCHT H (2001a): Ein Dorf in Nordost-Nigeria. Politische und wirtschaftlichen Transformation der bäuerlichen Kanuri-Gesellschaft. Göttinger Studien zur Ethnologie 6, 345 S.

KIRSCHT H (2001b): Masakwa farming in northeastern Nigeria. Ber. SFB 268 17: 33-60.

KrINGS M (2002): Neusiedler am Tschadsee. In ReIKAT A (ed.): Leben in Westafrika, Plexus Verlag, Amorbach, 112123 .

Le Bourgeois, T \& MerLier, H. (1993): Adventrop. Les adventices d'Afrique soudano-sahélienne. CIRAD-AC (ed.): Montpellier. $637 \mathrm{pp}$.

LÖHR D (2001): Masakwa from a linguistic point of view. Ber. SFB 268 17: 85-104.

Mordi, RI, NWAKa, GIC, Folorunso, OA, OHU, JO, BABABe, A, Ogunsola, OA, Esu, IE, Kaigama, BK, and OmeJe, MU (1991): Report of the soil characterizationof IBSRAM Vertisol; management project sites in northeastern Nigeria. International Board for Soil Research and Management Bangkok, 99 pp.

NEUmann K (2001): Masakwa farming in the Chad Basin of Northeast Nigeria- Introduction. In KAHLHEBER S \& NEUMANN K (eds.): Man and environment in the West African Sahel - an Interdisciplinary Approach. Ber. SFB 268 17: 9-13.

SKORUPINSKI T \& FRANKE-SCHARF I (1997): Auswirkungen anthropogener Nutzung auf Böden im nigerianischen Tschadbecken. Luftbildkartierungen von Deflationsschäden im Marte Local Government. Ber. SFB 268 9: 53-66.

THIEMEYER H (1997a): Naturräumliche Voraussetzungen für die Besiedlung des südwestlichen Tschadbeckens im Holozän. Zbl. Geol. Paläont. 1: 77-89. 
THIEMEYER H (1997b): Untersuchungen zur spätpleistozänen und holozänen Landschaftsentwicklung im südwestlichen Tschadseebecken (NE-Nigeria). Jenaer Geogr. Schr. 5: $127 \mathrm{~S}$.

Thiemeyer H (2002): Der Tschadsee - Binnenmeer im Herzen Afrikas. In ReIKAT A (ed.): Leben in Westafrika, Plexus Verlag, Amorbach, 98-103.

White, F. (1983): The vegetation of Africa. A descriptive memoire to accompany the Unesco/Aetfat/Unso vegetation map of Africa. Unesco Natural Resources Res. 20: 1- 356.

WitTig R (2005): Echinochloetea colonae classis nova. Etudes flor. veg. Burkina Faso 9, 11-18.

\section{AdDRESSES OF THE AUTHORS}

Dr. Mandingo Ataholo

Anzengruberstraße 16

92318 Neumarkt i.d.Oberpfalz, Germany

eMail: ataholo@hotmail.com

Prof. Dr. Rüdiger Wittig*

Institute of Ecology, Evolution and Diversity

Goethe-Universität

Max-von-Laue-Str. 13

D-60438 Frankfurt am Main, Germany

* and: Biodiversity and Climate Research

Center Frankfurt (BiK-F)

D-60325 Frankfurt am Main, Germany

eMail: r.wittig@bio.uni-frankfurt.de 